\title{
A retouched bone shaft from the Late Mousterian at Fumane cave (Italy). Technological, experimental and micro-wear analysis
}

\section{Diaphyse osseuse retouchée issue du Moustérien final de la grotte de Fumane (Italie). Analyse technologique, expérimentale et tracéologique}

\author{
Matteo Romandini ${ }^{\mathrm{a}}$, Emanuela Cristiani ${ }^{\mathrm{b}}$, Marco Peresani ${ }^{\mathrm{a}, *}$ \\ a Università di Ferrara, Dipartimento di Studi Umanistici, Sezione di Preistoria e Antropologia, Corso Ercole I d'Este, 32, \\ 44100 Ferrara, Italy \\ ${ }^{\mathrm{b}}$ McDonald Institute for Archaeological Research, University of Cambridge, Downing Street, CB2 3ER Cambridge, UK
}

\section{A R T I C L E I N F O}

\section{Article history:}

Received 23 June 2014

Accepted after revision 17 August 2014

Available online 26 October 2014

Handled by Marcel Otte

\section{Keywords:}

Mousterian

Retouch

Bone tool

Taphonomy

Zooarchaeology

\begin{abstract}
A B S T R A C T
This paper describes a retouched bone shaft found in a Late Mousterian layer at Fumane Cave, northern Italy. The interpretation of the anthropic nature of the retouch is based on the identification of specific morpho-technological markers through experimentation. An integrated taphonomic and technological analysis was applied to the archaeological artifact. The evidence suggests that the bone shaft modifications involved the use of direct percussion through a transfer of technical knowledge from flint knapping. However, this does not necessarily imply that this technique was used in the absence of a more effective one. Similar cases of the use of bone as raw material for tool manufacturing are documented in the Lower Palaeolithic, and might have been related to the lack of appropriate lithic raw material, although this is not the case for Fumane cave.
\end{abstract}

(C) 2014 Académie des sciences. Published by Elsevier Masson SAS. All rights reserved.

\section{R É S U M É}

Cet article présente un outil en os retouché trouvé dans le niveau Moustérien final de la grotte de Fumane dans le Nord de l'Italie. L'interprétation de la nature anthropique des retouches est basée sur l'identification de marqueurs morpho-techniques spécifiques qui ont été mis en évidence lors d'expérimentations. Ces analyses taphonomiques et technologiques ont été appliquées à l'artefact archéologique. Les résultats indiquent que la modification de l'outil en os nécessite l'utilisation de la percussion directe par un transfert de connaissances techniques du débitage du silex. Toutefois, cela n'implique pas nécessairement que cette technique a été utilisée en l'absence d'une autre plus efficace. Bien que des cas similaires de l'utilisation d'os comme matière première pour la fabrication d'outils documentés dans le Paléolithique inférieur aient pu être reliés à un manque de matière première lithique appropriée, cela n'est pas le cas pour la grotte de Fumane.

(c) 2014 Académie des sciences. Publié par Elsevier Masson SAS. Tous droits réservés.

\footnotetext{
* Corresponding author.

E-mail address: marco.peresani@unife.it (M. Peresani).
} 


\section{Introduction}

Difficulties in identifying retouch technology applied on bones in Lower and Middle Palaeolithic are due to different taphonomic agents, which acted on faunal remains. In general, the level of bone modification is low, as are the intentional breakage patterns that may partially overlap those produced by carnivores (Brain, 1981; Chase and Nowell, 1998; d'Errico and Villa, 1997; d'Errico et al., 1998; Domínguez-Rodrigo et al., 2009; Galán et al., 2009; Koby, 1943; Villa, 1991; Villa and d'Errico, 2001). While, there is little evidence for the use of retouch or more formal techniques (e.g, splitting, scraping, polishing) with respect to the enormous bulk of raw material available, such as bone, antler or ivory, the use of unmodified bone flakes as hammers for stone flake retouching is widely documented (Jéquier et al., 2012; Mozota Holgueras, 2009; Valensi, 1996).

An overview of the ancient bone technology reveals that the earliest deliberate modification of bones by retouch dates to MIS9 at Gran Dolina and Bolomor Cave (Spain) and at Qesem cave (Israel) (Blasco et al., 2013; Rosell et al., 2011). Bifaces, choppers, scrapers and denticulates made on bone flakes from large herbivores, such as bovids, horses, deer and proboscideans were also found in several Lower Acheulean sites in central Italy (Anzidei, 2001; Anzidei et al., 1989; Biddittu and Celletti, 2001; Cassoli et al., 1982; Saccà, 2012; Segre Naldini et al., 2009; Villa et al., 1999), Germany (Bilzingsleben-Mania and Mania, 2005) and Hungary (Vertesszöllös - Dobosi, 2001). Acheulean bone tools are dimensionally and morphologically comparable to lithic implements, with invasive and bifacial detachments, regularly positioned on the side. Outside Europe, retouch technology is ephemeral for the MSA in Africa, although it is considered amongst the repertoire of techniques for bone modification associated to modern human behaviour (Henshilwood et al., 2001; McBrearty and Brooks, 2000). The earliest example is provided from Blombos Cave, South Africa, ca. 75-77 ka BP, where a fresh bovid long bone was modified into an end-scraper and used (d'Errico and Henshilwood, 2007).

In the European Middle Palaeolithic, retouched bone artefacts were rarely investigated for taphonomic and technological traces (Bordes, 1961; Cabrera Valdes, 1984; Vincent, 1993) and, when this was done, a number of specimens can be considered as pseudo-artefacts (d'Errico and Villa, 1997). More reliable evidence is represented by a bifacially retouched bone fragment from Vaufrey Cave (France) (Vincent, 1988), some denticulated diaphyses and a pointed tool on auroch mandible (Rosell et al., 2012) from Abric Romaní (Spain), and some trihedral picks on tibia of rhinoceros found at Gruta Nova de Columbeira (Portugal) (Barandiarán et al., 1971) dated to $87.1 \pm 6.3$ ka BP (Zilhão et al., 2011). To indicate that Neanderthals during the Middle Palaeolithic made use of a set of bone technologies, there are the rare tools worked by abrasion that are dated to the first half of MIS3 from Salzgitter-Lebenstedt, Germany (Gaudzinski, 1999) and the bone smoothers recovered from the Mousterian of Acheulean Tradition at Pech-de-l'Azé I and Abri Peyrony, France (Soressi et al., 2013). It follows that each single element yielding additional data about the specific Neanderthal techniques and skills is fundamental in order to evaluate the technological behaviour of this species.

To date, criteria for identifying technological retouches on bones have never been made fully explicit. The interpretation of anthropic retouched bones has mainly followed the same criteria used in stone knapping. Diagnosis and identification of anthropic retouch has mostly been based on the occurrence of invasive removals with classic attributes of percussion flaking (Saccà, 2012; Villa and Bartram, 1996). The repetition and uniformity of the blows (with percussion bulb scars) as well as the regular outline of the retouched sides have also been considered as important markers of technological retouch. In particular, the regular pattern of symmetric detachments excludes the activity of carnivores and/or butchery marks produced while fracturing bone for recovering marrow. While few modified bones have been interpreted as tools on the basis of experimental data related to the use of percussion techniques (Biberson and Aguirre, 1965; Vincent, 1988,1993), the results are not always convincing when bone assemblage formation processes are taken into consideration (Villa and Bartram, 1996). For instance, at Prolom (Stephanchuk, 1993) and Bois Roche systematic taphonomic and contextual analysis identify carnivore activity (e.g., hyena) as the main agent for pseudo-technological traces on bones or perforated artefacts (d'Errico and Villa, 1997 contra Vincent, 1993).

To facilitate the recognition of deliberately modified bones, this paper presents the results of an integrated taphonomic, technological, and functional analysis of one bone scraper recovered from the final Mousterian of Fumane Cave, northern Italy, with the aim of providing new data about early retouch technology. We believe that on methodological grounds this discussion is relevant for many other case studies worldwide where one finds old prehistoric evidence of retouch technology on bone.

\section{Materials and methods}

Fumane Cave (Lessini Mountains, Veneto) records the MP-UP transition with a finely layered sedimentary succession preserving several Late Mousterian levels, covered by Uluzzian and Proto-Aurignacian levels (Broglio et al., 2006; Higham et al., 2009; Peresani, 2012; Peresani et al., 2011a). The Latest Mousterian is recorded in a stratigraphic complex named A5-A6 composed of layers A5, A5 + A6, and $A 6$. The bone scraper was found in layer $A 5+A 6$ in the rear of the cave (square 120c), associated with dispersed charcoal fragments, flaked stones, bones, and few hearths. The chronometric refinement of the ${ }^{14} \mathrm{C}$ data sets layers $\mathrm{A} 5$ and $\mathrm{A} 5+\mathrm{A} 6$ to $42.3-39.8 \mathrm{ky}{ }^{14} \mathrm{C}$ BP. The bone scraper has been subjected to taphonomic, techno and use-wear analyses, the results of which have been compared to the experimental data. Taxonomical and anatomical determinations were made after comparison with the faunal collection stored at the University of Ferrara (Laboratory of Archaeozoology and Taphonomy). Taphonomic alterations have been analysed at low and high magnification. Measurements of the specimen included length, width and thickness. For the interpretation of the traces we have referred to the available scientific literature (Blasco et al., 2008; Fischer, 
1995; Olsen, 1989; Shipman and Rose, 1988; Villa and d'Errico, 2001). The functional analysis has directly been carried out on the specimen, without the use of resin replicas. The appearance, development, location, and distribution of manufacturing and use-wear traces have been observed with a stereoscope Nikon-SMZ-10 (magnification $0.75-70 \times$ ) and a metallographic microscope Nikon Eclipse ME 600 (magnification 10-200 ×). The interpretation of technological and functional modifications has been based on both criteria defined in the scientific literature (Christidou, 1999; Legrand, 2007; Maigrot, 1997) as well as on the experimental comparison.

\section{The context of the retouched bone}

A total of 3096 remains of mammal species were identified among the 171,257 bone fragments recovered in layer A5+A6. The number of identified bones is low due to the high rate of bone fragmentation (more than $88.8 \%$ are smaller than $2 \mathrm{~cm}$ ) and combustion (47.8\%). These conditions are due to a set of depositional and postdepositional processes also noted in other fully anthropic contexts (Morin, 2010). The number of bones smoothed by different natural mechanisms, like trampling, rolling, and microscraping is very low (5.4\%). Root marks are the most common alterations identified on bones (26.8\%), followed by surface microfissures from weathering and/or weathering cracks (20.4\%), manganese stains (17.6\%) and exfoliations (6.4\%). Some concretionary fragments (17.6\%) were concentrated near the external area at the limit of the drip-line, while the few with trampling abrasions (0.5\%-total remains 919) in the east part of the cave are associated with the highest stoniness of the layer. There is high incidence of burned remains that could suggest the use of butchering refuse, rich in fats, as fuel for fire. Amongst the burned fragments, $88.0 \%$ were subject to moderate combustion $\left(200-500^{\circ} \mathrm{C}\right.$, black/brown), while $12 \%$ were calcined $\left(>700^{\circ} \mathrm{C}\right.$, grey/white). At a general level, these patterns and phenomena are similar to evidence from the Mousterian unit A9 with Discoid technology, and to other anthropogenic deposits in the region (Romandini et al., 2014).

The macromammal assemblage is composed mainly of red deer and roe deer, elk, ibex and chamois, and giant deer have also been recognized. Fox, wolf and bears are the most numerous carnivores. Avifaunal bones from different species also bear traces of human modifications (Peresani et al., 2011b). With the exception of the wolf, carnivore remains show skinning and defleshing butchering marks. This data, together with the scarcity (No. 71) of carnivore gnawing on bones as well as a consistent sample of anthropic marks, suggest the anthropic nature of bone accumulation in this layer (Peresani et al., 2011a). Intense intentional breakage of undetermined bones is also testified by many percussion cones (No. 1951) and notches as well as by impact scars ( $n^{0} 466$ ). Most of the ungulates yielded anthropic traces, especially red and roe deer. When considering the whole ensemble of faunal remains, butchering traces have been identified on 1442 remains, determined at the level of the species (butchering rate is the $47 \%$ of the total NISP) and 1954 determined bones (1.2\% of the total undetermined). Tibias, femura and metapodials, radii and humeri from Cervids (red deer, roe deer, and very large specimens of giant deer or elk), and at lesser extent from other ungulates fragmented from extracting marrow were used as retouchers (total number A5 + A6 layer: 48; total number from the A5-A6 complex: 131). While some of the surfaces were scraped before being used (probably to remove residues of meat and tendon or the periosteum), no further preliminary preparation is documented (Jéquier et al., 2012). Punctiform and linear impressions, striations and pits usually characterize functional areas on retouchers. Up to three different functional zones can be identified on each retoucher, although the majority of the pieces show a single functional zone. Interestingly, 28 out of the 516 fragmented shafts $>5 \mathrm{~cm}$ of length sampled in that study (Jéquier et al., 2012) were recycled as retouchers, whereas only one was turned into the scraper described in this paper.

As for the 280 deer fragments recovered in layer A5 + A6 (Fig. 1A), coordinates have been recorded for ungulates remains, which are almost totally concentrated on the east side of the investigated area, close to the NE stone wall. In the remaining part of the investigated area, red deer bones are present and become sporadic in the external area to the SE (Fig. 1B). In A5+A6, bigger faunal remains (1823 remains $\geq 3 \mathrm{~cm}$ of length) are concentrated with a frequency of 10-28 remains per square (Fig. 1C). Most of the carnivore remains with anthropic traces are located at the entrance to the tunnels $B$ and $C$. The spatial distribution of bones with impact traces (notches, percussion marks and cones) shows concentrations of intentionally modified remains and percussion cones on the eastern side, along the inner part until tunnel C (Fig. 1D-E).

\section{Experimental production and use of bone retouched edges}

Experimental retouched edges have been shaped on eight flakes produced for recovering of marrow as a primary goal, using direct percussion on 6 fresh radii extracted from 3 red deer carcasses previously defleshed by vultures. The bones were handled and placed on a base during percussion (Fig. 2a1-a6). The location of the impacts affected the morphology of the resulting flakes. Namely, spiral fractures longitudinal to the long axis of the diaphysis can be considered the best way to open the bone and extract the marrow. These fractures were produced by striking on the medial-lateral part of the diaphysis, close to the epiphyses. Diversely, transversal fractures created by impacting the postero-dorsal side of the bone are not functional for marrow extraction. Normally, only one blank was morphologically suitable for producing a notched edge through marginal direct percussion. In very few cases, up to three or four notches have been obtained.

Fat and periosteum were scraped off the bones in order to make technological work easier. This activity produced typical striations, visible on the negatives even after direct percussion. Stone hammers and flint blocks of different size, weight $(1.5-0.5 \mathrm{~kg})$ and texture were used for retouching (Fig. 2a1-a6). On the thickest portions of the edge, generally in their medial or lateral sides, retouch 

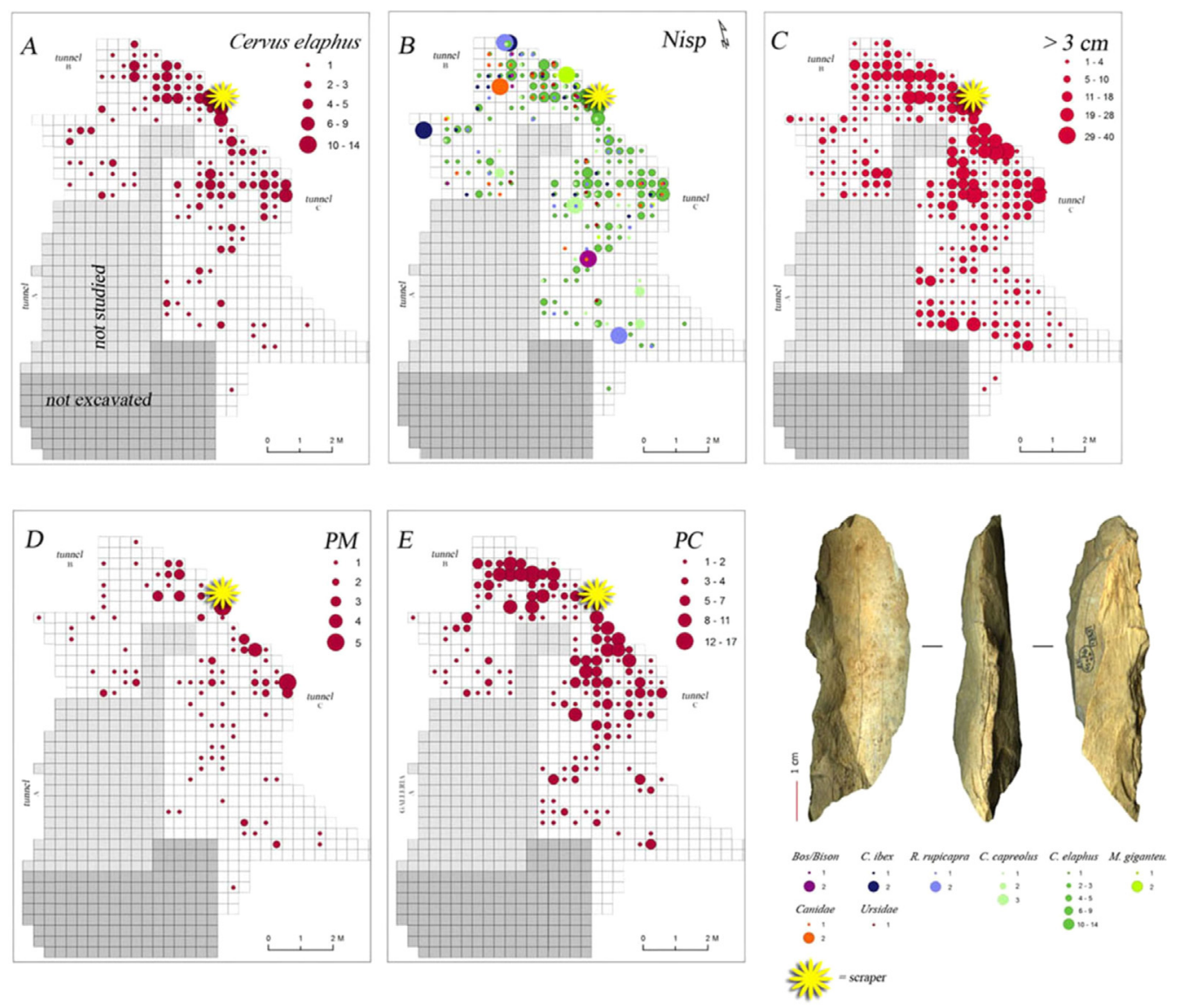

Fig. 1. (Colour online.) Spatial distribution of different categories of faunal remains and location of RF1395 scraper. $P M=$ percussion marks; $P C=$ percussion cones.

Fig. 1. (Couleur en ligne.) Distribution spatiale des différentes catégories de restes fauniques et emplacement du racloir RF1395. PM = marques de percussion; $\mathrm{PC}=$ cônes de percussion.

was carried out easily with an edge close to $60^{\circ}$. This task was facilitated by holding the bone against a base (Fig. 2a2-a6). In four cases, while retouching the bone blank through alternate retouch, the diaphysis broke after 4-5 retouches were produced.

Experimental scrapers were very effective on different materials (fresh and dry hide, fresh and dry wood, fresh bone with meat), and use-wear traces started to develop after 5 minutes. They were held with one or both hands, and both the dorsal and the ventral edges of the scrapers were successfully used in unidirectional, convergent-divergent, or alternate movements. Wood and bone scraping produced intense rounding much quicker than hide or meat processing (Table 1; Figs. 2 and $4 a-b)$. While diagnostic differences can be identified in the invasiveness and the development of rounding on the edge according to the different materials processed and the specific motions performed with the experimental tools (e.g., scraping hide vs. scraping wood), all the activities carried out have developed modifications oriented and distributed according to the movement performed with the scraper (Table 1; Fig. 3a-f). Differences in the invasiveness of the use-wear traces have been observed according to the high or low working angle, while very flat rounding developed while working wood. Different use-wear traces have always developed along the used edge and never on the medullar ridges of the bones, as those were not in contact with the worked material during the activity.

\section{Archaeological results}

On the basis of the experimental results, we suggest that the portion of diaphysis exploited for the manufacture of RF1395 was deliberately shaped by direct percussion on the anterior and posterior surfaces, successively. The breakage planes suggest that the bone was retouched when still fresh. On the dorsal face of the bone, it is possible to observe a sequence of five detachments obtained using the $60^{\circ}$ natural angle of the radius, and its central mesial edge is characterised by a slightly narrower angle of $55^{\circ}$ due to the absence of the trabecular frame along the medullar channel. Notches and detachments on the anterior face are thin, moderately invasive, and disposed in sequence (Fig. 4A). On the exploitable edge, a "pseudo" percussion cone is still visible (Fig. 4A/\#), whereas on the medullar face (Fig. 4B) four invasive notches overlap the previous opposed ones, removing their impact points. In one case, the notches on both faces share a common 

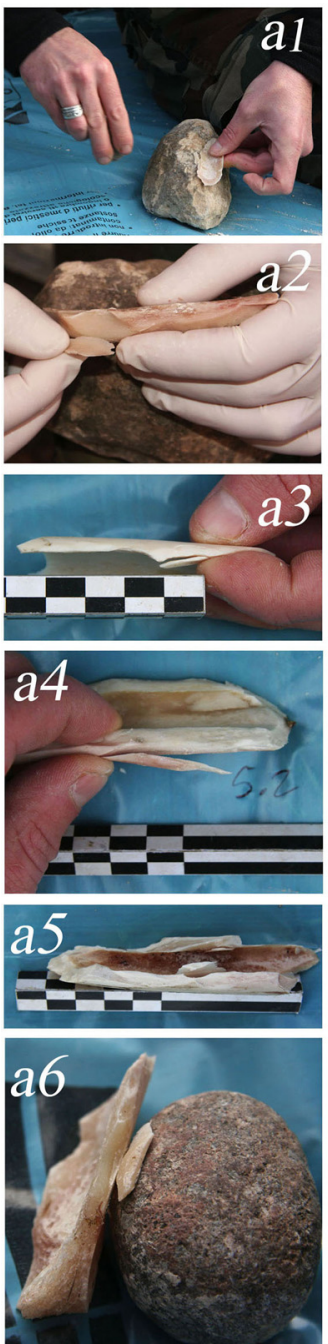
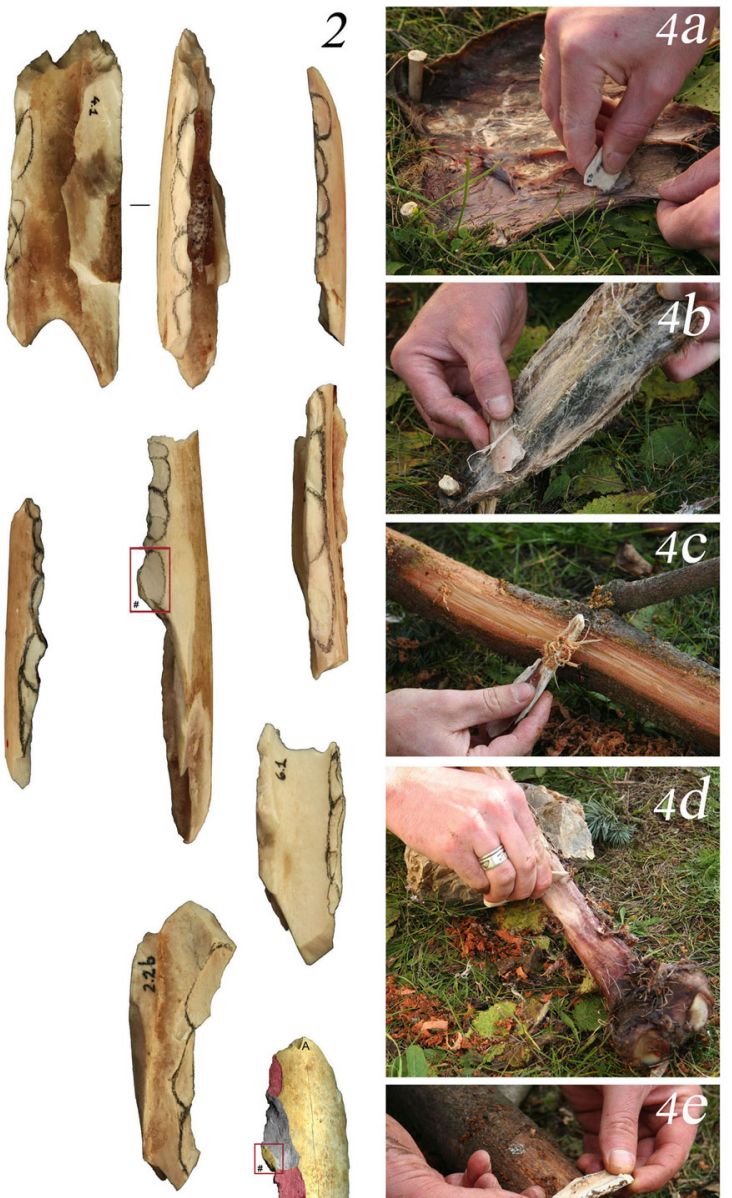

$1 \mathrm{~cm}$
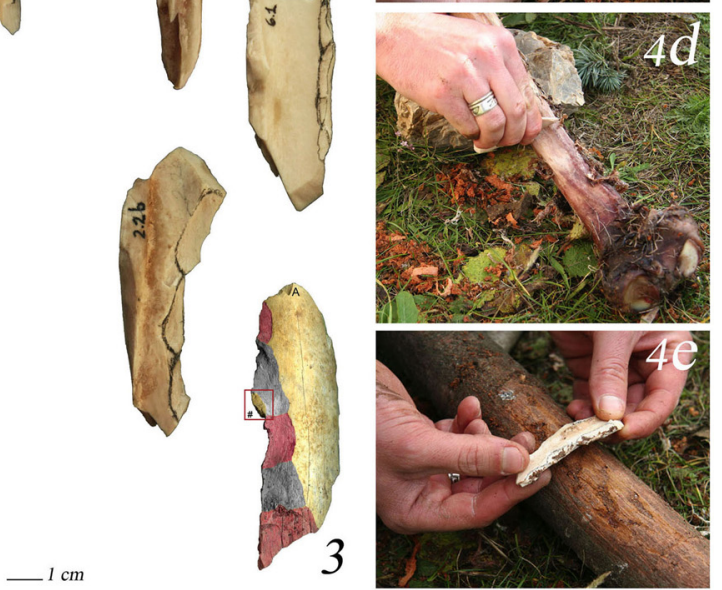

Fig. 2. (Colour online.) Experimental production and use of bone retouched edges: (a1-6) retouching of deers' radii; (2) bone scrapers with retouch detachments marked out; (3) the RF1395 scraper. (\#) impact cones; (4a-e) use of experimental scrapers on different materials (fresh and dry hide, fresh and dry wood, fresh bone with meat).

Fig. 2. (Couleur en ligne.) Production expérimentale et utilisation d'os retouchés sur les bords : (a1-6) retouche des radius de cerf ; (2) racloirs en os avec mise en évidence des enlèvements ; (3) racloir RF1395. (\#) cônes de percussion; (4a-e) Utilisation de racloirs expérimentaux sur différents matériaux (peau fraîche et sèche, bois vert et sec, os frais avec de la viande).

impact point, which is still visible along the bone edge (Fig. 4C). The suite of gestures reveals the exploitation of the two opposed faces, hierarchically related from the medial diaphysis angle. While retouches on bone shafts can be produced by carnivore activity, the latter are generally smaller and isolated and always associated with punctures pits and score-pits (Blumenshine, 1995; Domínguez-Rodrigo and Piqueras, 2003; Fischer, 1995).

At high magnification, the surfaces of the bone scraper RF1395 are characterized by various post-depositional alterations, such as traces of dissolution caused by roots, tiny carbonate concretions, dehydration cracks, and soil striations. On the ventral surface, detachments can be observed along the right edge and along dehydration cracks. Post-depositional edge rounding is also developed along the natural and retouched edges of the tool as well as on the ventral surface and along the edges of the marrow cavity (Fig. 3g). These post-depositional modifications also characterize unmodified bone fragments coming from the layer A5 + A6 of Fumane Cave. On the experimental tools, rounding is always associated with striated areas; their distribution, orientation and characteristics are diagnostic of the different movements performed and materials worked with the bone scraper during the activity (e.g., fresh and dry wood, fresh and dry hide, meat and bone). While, on RF1395, developed rounding is never associated with densely striated areas at a macroscopic level rounded, striated spots with tiny depressions oriented according to the striations have been identified at high magnification (Fig. $3 m-n)$. These micro use-wear traces are compatible with modifications produced on experimental tools after processing dry wood for a short time. On this basis, 

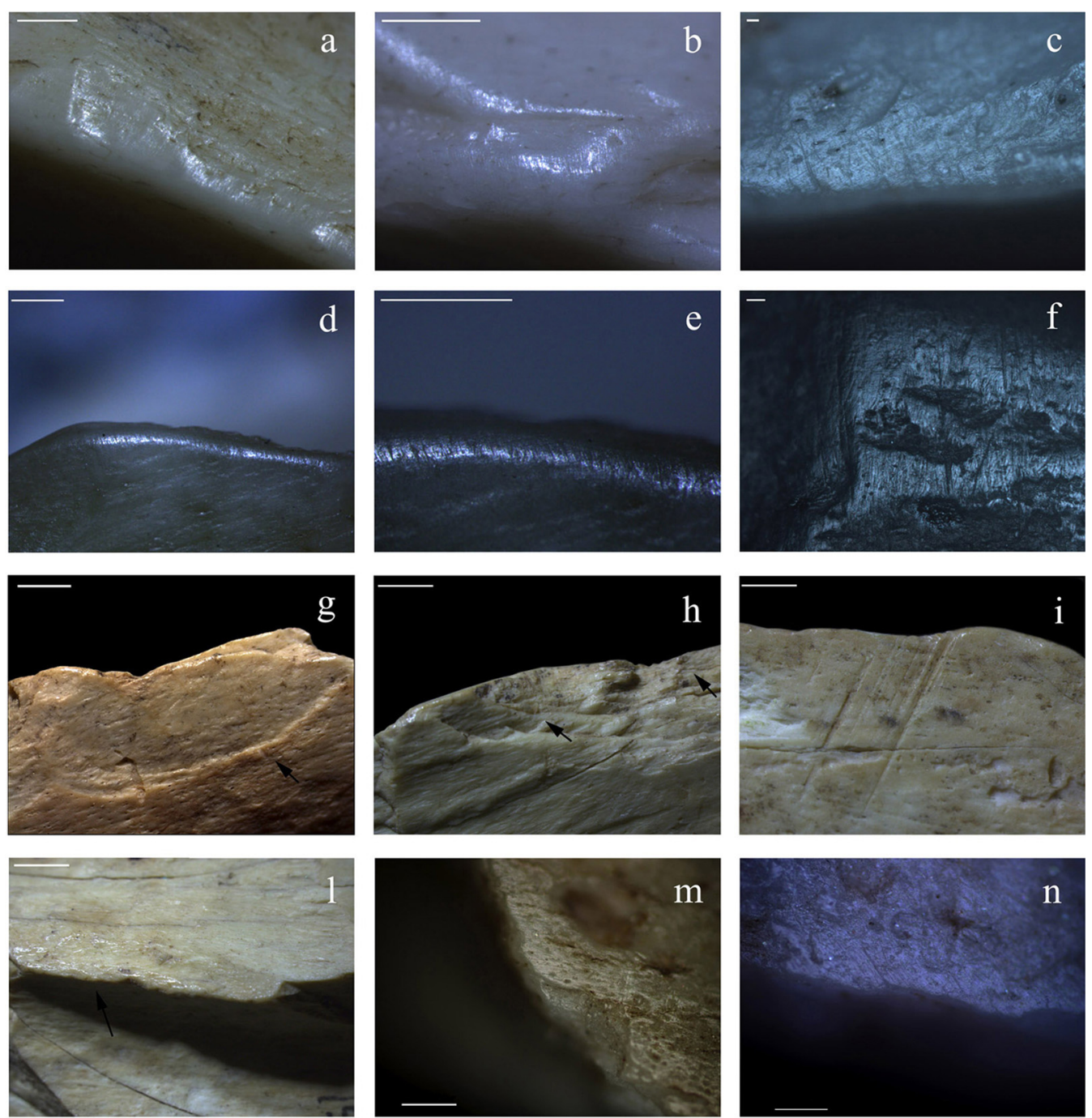

Fig. 3. (Colour online.) Experimental (EXP) use-wear traces and post-depositional (PD) as well as use modifications on RF1395: (a) EXP macro traces from dry wood scraping. Note the shiny surfaces and the flat profile of the rounding and the high density of striations; (b) close-up on a densely striated and rounded area produced after scraping dry wood; (c) close-up on EXP micro trace produced after scraping dry wood. Note the invasiveness of rounding and striations and the small, elongated pits along the edge; (d) EXP macro traces from dry skin scraping. Note the very deep striations on the edge, the less invasive distribution of the rounded areas on the tool's edge and the more smoothed profile with respect to Fig. 4A; (e) close-up on striations produced after scraping dry skin; (f) close-up on EXP micro traces produced after scraping dry hide. Note the limited invasiveness of the traces into the natural depression of the bone and the deep striations and the overall round profile of the worn area; (g) RF1395. Localised rounding along the edge of the tool. The arrow shows a number of PD striations produced by friction with soil particles; (h) RF1395. Localised series of PD striations produced by trampling and sedimentary particles. The arrows on the right indicate PD dehydration cracks of the tissue; (i) RF1395. Edge rounding and striations caused by friction with sedimentary particles; (I) RF1395. PD edge rounding located on the crests of the marrow cavity and details of dehydration cracks of the tissue; (m-n) RF1395. Close-up on micro use-wear traces. Bar: $1 \mathrm{~mm}$ in a-e, g-l; $200 \mu \mathrm{m}$ in $\mathrm{f}, \mathrm{m}-\mathrm{n}$.

Fig. 3. (Couleur en ligne.) Traces d'utilisation expérimentales (EXP), traces post-dépositionnelles (PD) et modifications d'utilisation sur RF1395 : (a) macrotraces EXP dues au raclage de bois sec. Noter les surfaces lisses/brillantes, le profil plat de l'arrondi et la forte densité de stries qui le caractérise; (b) focus sur une zone densément striée et arrondie, produite après raclage de bois sec; (c) focus sur microtraces EXP produites après raclage de bois sec. Noter le caractère invasif de l'arrondi, les stries et les petits pits allongés le long du bord; (d) macrotraces EXP, après raclage de peau sèche. Noter les stries très profondes sur le bord, la distribution moins invasive des zones arrondies sur le bord de l'outil et le profil plus émoussé par rapport à la Fig. 4A; (e) focus sur les stries produites après raclage de peau sèche; (f) focus sur microtraces EXP produites après raclage de peau sèche. Noter l'invasion limitée des traces dans la dépression naturelle de l'os, les stries profondes et le profil arrondi sur l'ensemble de la zone usée ; (g) RF1395. Arrondi localisé le long du bord de l'outil. La flèche montre une série de stries PD produites par friction avec des particules de sol; (h) RF1395. Séries localisées de stries PD produites par le charriage à sec et les sédiments. Les flèches à droite indiquent les fissures de déshydratation PD du tissu ; (i) RF1395. Bord arrondi et stries causés par friction avec des particules sédimentaires; ( (l) RF1395. Arrondi PD situé sur les crêtes de la cavité de la moelle osseuse et détails des fissures de déshydratation des tissus ; (m-n) RF1395. Focus sur les microtraces d'utilisation et d'usure. Échelle : $1 \mathrm{~mm}$ pour a-e et g-1; $200 \mu \mathrm{m}$ pour f, m-n. 
Table 1

Materials worked with experimental bone scrapers and results (R-rounding; S-striations).

Tableau 1

Matériaux travaillés avec les racloirs en os expérimentaux et résultats (R-arrondissements ; S-stries)

\begin{tabular}{|c|c|c|c|c|c|c|}
\hline Code & Worked material & Prehension & Movement & Time & Effectiveness & Use-wear traces description \\
\hline 2.2 & $\begin{array}{l}\text { Dry conifer } \\
\text { wood + resin }\end{array}$ & $\begin{array}{l}\text { Two handed } \\
\text { (dorsal) }\end{array}$ & $\begin{array}{l}\text { Unidirectional } \\
\text { towards the } \\
\text { experimenter }\end{array}$ & $3^{\prime}$ & Excellent & $\begin{array}{l}R \text { : very shiny, very developed with flat profile and } \\
\text { invasive distribution into the natural depressions of } \\
\text { the bone topography } \\
S \text { : very numerous, long, wide and deep. Their } \\
\text { invasiveness varies according with the working angle }\end{array}$ \\
\hline 3.1 & $\begin{array}{l}\text { Fresh conifer } \\
\text { wood + resin }\end{array}$ & $\begin{array}{l}\text { One handed } \\
\text { (dorsal) }\end{array}$ & Bidirectional & $3^{\prime}$ & Excellent & $\begin{array}{l}R \text { : Shiny, very developed with flat profile and invasive } \\
\text { distribution into the natural depressions of the bone } \\
\text { topography } \\
S \text { : very numerous, long, wide and deep. Their } \\
\text { invasiveness varies according with the tool's working } \\
\text { angle }\end{array}$ \\
\hline 5.1 & $\begin{array}{l}\text { Fresh bone }+ \text { dry } \\
\text { meat }\end{array}$ & $\begin{array}{l}\text { One handed } \\
\text { (dorsal) }\end{array}$ & $\begin{array}{l}\text { Unidirectional } \\
\text { towards the } \\
\text { experi- } \\
\text { menter + bidirectiona }\end{array}$ & $\begin{array}{l}2^{\prime} \\
\text { al }\end{array}$ & Excellent & $\begin{array}{l}R \text { : Not very shiny, developed, not invasive distribution } \\
\text { into the natural depressions of the bone topography } \\
S \text { : not numerous, long, wide and deep. Variable } \\
\text { invasiveness according with the tool's working angle }\end{array}$ \\
\hline 5.2 & $\begin{array}{l}\text { Fresh conifer } \\
\text { wood + resin }\end{array}$ & $\begin{array}{l}\text { One handed } \\
\text { (dorsal) }\end{array}$ & $\begin{array}{l}\text { Unidirectional } \\
\text { towards the } \\
\text { experi- } \\
\text { menter + bidirectiona }\end{array}$ & $\begin{array}{l}3^{\prime} \\
\text { al }\end{array}$ & Excellent & $\begin{array}{l}R \text { : very shiny, very developed with flat profile and } \\
\text { invasive distribution into the natural depressions of } \\
\text { the bone topography } \\
S \text { : very numerous, long, wide and deep } \\
\text { Variable invasiveness according with the tool's } \\
\text { working angle }\end{array}$ \\
\hline 5.3 & Fresh skin & $\begin{array}{l}\text { One handed } \\
\text { (dorsal) and } \\
\text { medullary }\end{array}$ & $\begin{array}{l}\text { Unidirectional } \\
\text { towards the } \\
\text { experimented and } \\
\text { far from the } \\
\text { experimenter }\end{array}$ & $5^{\prime}$ & Good & $\begin{array}{l}R \text { : Shiny, developed, round profile, invasive } \\
\text { distribution into the natural depressions of the bone } \\
\text { topography } \\
S \text { : very numerous, short, wide and deep. Their } \\
\text { invasiveness varies according with the working angle. }\end{array}$ \\
\hline 6.1 & $\begin{array}{l}\text { Dry conifer } \\
\text { wood }+ \text { resin }\end{array}$ & $\begin{array}{l}\text { One handed } \\
\text { (dorsal) }\end{array}$ & $\begin{array}{l}\text { Unidirectional } \\
\text { towards the } \\
\text { experimented and } \\
\text { far from the } \\
\text { experimenter }\end{array}$ & $3^{\prime}$ & Excellent & $\begin{array}{l}R \text { : Very shiny, developed with flat profile and invasive } \\
\text { distribution into the natural depressions of the bone } \\
\text { topography } \\
S \text { : very numerous, long, wide and deep } \\
\text { Their invasiveness varies according with the working } \\
\text { angle }\end{array}$ \\
\hline 6.2 & $\begin{array}{l}\text { Fresh bone }+ \text { dry } \\
\text { and fresh meat }\end{array}$ & $\begin{array}{l}\text { One handed } \\
\text { (dorsal) }\end{array}$ & $\begin{array}{l}\text { Unidirectional } \\
\text { towards the } \\
\text { experimented and } \\
\text { far from the } \\
\text { experimenter }\end{array}$ & $4^{\prime}$ & Excellent & $\begin{array}{l}R \text { : Not very shiny, developed, flat profile, not invasive } \\
S \text { : numerous, long, wide and deep }\end{array}$ \\
\hline 6.4 & Dry skin & $\begin{array}{l}\text { Single-handed } \\
\text { dorsal and one } \\
\text { medullary }\end{array}$ & $\begin{array}{l}\text { Unidirectional } \\
\text { towards the } \\
\text { experimented and } \\
\text { far from the } \\
\text { experimenter }\end{array}$ & $5^{\prime}$ & Excellent & $\begin{array}{l}R: \text { Shiny, developed, round profile, not invasive } \\
S \text { : very numerous, short, wide and deep } \\
\text { Their invasiveness varies according with the working } \\
\text { angle }\end{array}$ \\
\hline
\end{tabular}

we cannot exclude that post-depositional modifications affecting the surfaces of RF1395 might have altered the eventual and more developed traces produced after using the bone scraper on wood.

\section{Discussion and conclusions}

Fumane represents a Neanderthal referential site during MIS3, due to the bulk of evidence like lithic and bone remains related to multiple occupational events. At the site, the use of bone splinters for retouching lithic artefacts is well known, and bones from hunted animals represented an alternative raw material, which Neanderthals expediently exploited.

Our experimental activity as well as the results of the technological and taphonomic analyses, supports the interpretation of the retouched bone RF1395 from Fumane as a scraper. In particular, the technological analysis has pointed out that the medial portion of the radius was selected and retouched through an array of gestures carried out on the two opposite faces of the bone. This part of the diaphysis was preferred for its thickness and for the narrow exterior curvature of the bone. The interpretation of the deliberated modified edge has been based on morphological and technological indicators, such as shape and location of the retouches, their uniform distribution, the presence of percussion bulbs, and the regularity of the edge profile. The appearance of the bifacial, planar, continuous, and overlapping retouches along the edge of RF1395 differs from most typical taphonomic traces (e.g, carnivore gnawing, rodents activity, trampling, and sediment pressure) and from the anthropic modifications produced after green bone breakage for marrow recovery (Backwell and d'Errico, 2001; Blasco et al., 2008; Brain, 1981; Domínguez-Rodrigo et al., 2009; Fischer, 1995; Galán et al., 2009; Olsen, 1989; Shipman and Rose, 1988; Villa and d'Errico, 2001). Rather, modifications on RF1395 can be compared with the continuous unifacial or bifacial retouches made on thin dihedral edges of the midshafts from Gran Dolina (Rosell et al., 2011), with the invasive 


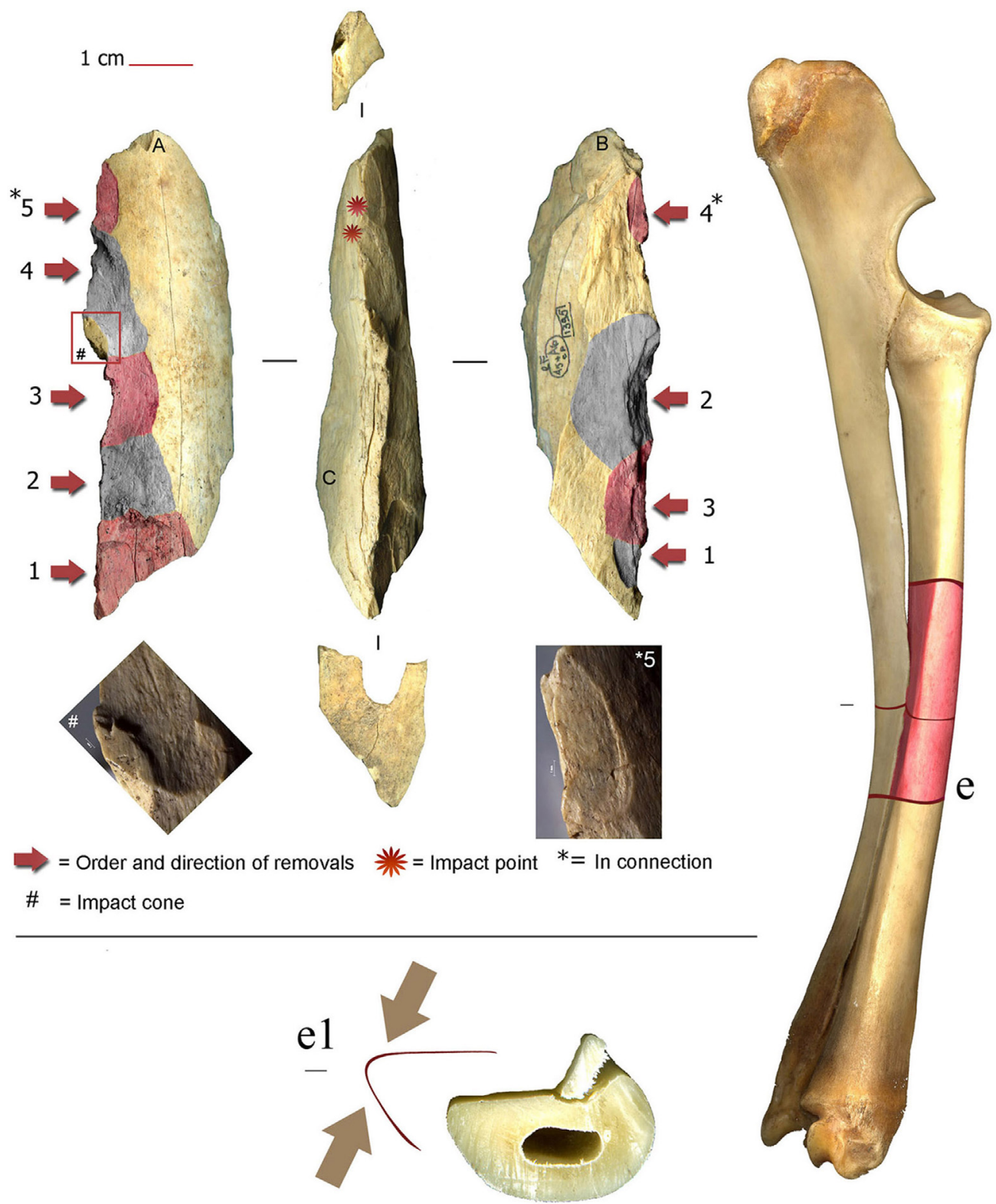

Fig. 4. (Colour online.) Bone scraper and scheme of the tool manufacture: (e) radius-ulna of Cervus elaphus; in red the portion represented by RF1395; (e1) section of the radius and angle detail exploited.

Fig. 4. (Couleur en ligne.) Racloir et schéma de la fabrication de l'outil sur os : (e) radius-ulna de Cervus elaphus ; en rouge, la partie représentée par RF1395 ; (e1) section du radius et détail de l'angle exploité.

and bifacial detachments regularly positioned on the side of some Acheulean bone artefacts (Biddittu and Segre, 1982; Segre Naldini et al., 2009) and clustered in a distinct pattern (Anzidei et al., 1989), on the bone fragment from Vaufrey Cave (Vincent, 1988), but also with the continuous scaled removals observed on the bone from Blombos Cave (d'Errico and Henshilwood, 2007). Nevertheless, Fumane scaper is different from the denticulated artefacts and the pointed tool from Abric Romaní (Carbonell et al., 1996), as well as and the trihedral pick made on rhinoceros tibia from Gruta Nova de Columbeira (Barandiarán et al., 1971), which marks out a variability in the way these flakes were modified. Our experimental results have also demonstrated that the angle and length of the edge of the bone scraper was potentially functional for cutting or scraping various materials (e.g., hide and wood). Although post-depositional agents partially affected the way usewear traces preserved on the tool, a brief utilization of the scraper for woodworking cannot be excluded on the basis of the microscopic analysis and experimental comparison.

In order to better characterize the technological aspects related to the production of the bone scraper, the possibility that the retouch represented an outcome of the production of bone retouchers has also been considered, 
as this was documented at the site Axlor, level D (Spain) (Mozota Holgueras, 2009). While the technological analysis of 130 bone retouchers carried out at this site show that in six cases tool blanks were prepared by percussion on the lateral sides and/or on the proximal parts, none of the 48 bone retouchers coming from levels A5 and A5 + A6 and 83 from level A6 of Fumane were extracted by percussion (Jéquier et al., 2012). Additionally, the detachments along the sides as well as on the proximal extremity of bone retoucher blanks are always more isolated than the ones characterizing the retouches on RF1395.

As a bone retouched tool, RF1395 is unique in the A5A6 stratigraphic complex as well as across the whole Late Mousterian sequence at Fumane. The technological characteristics of this tool clearly indicate that during the Middle Palaeolithic at Fumane, the exploitation of bone as raw material involved the use of direct percussion through a transfer of technical knowledge from flint knapping. While gestures are comparable to the operational sequences involved in flint knapping, this does not necessarily imply that this technique was used in the absence of a more effective one. Also, while side-scrapers are the most abundant category of retouched lithic tools, no morpho-types similar to the bone scraper are documented in the lithic industry at the site. In various Lower Palaeolithic contexts the use of bone as raw material for tool manufacturing has been related to the lack of appropriate lithic raw material in the surrounding area (Anzidei, 2001; Dobosi, 2001; Gaudzinski et al., 2005). Yet, archaeological evidence for bone modification by retouch is absent during the whole Middle Palaeolithic at Fumane. Consequently, we cannot exclude that the use of bone scrapers might have represented the result of sporadic events although the direct percussion represents the primary technique used in the manufacture of stone artefacts at this site. In conclusion, our results support the idea that the technological performances of Neanderthals involving the use of bone as raw material were variable but still at nascent level.

\section{References}

Anzidei, A.P., 2001. Tools from elephant bones at La Polledrara di Cecanibbio and Rebibbia - Casal de' Pazzi. In: Cavarretta, G., Gioia, P., Mussi, M., Palombo, M.R. (Eds.), The World of Elephants. Proceedings of the First International Congress. Consiglio Nazionale delle Ricerche, Roma, pp. 415-418.

Anzidei, A.P., Angelelli, A., Arnoldus-Huyzendveld, A., Caloi, L., Palombo, M.R., Segre, A.G., 1989. Le gisement Pléistocène de la Polledrara di Cecanibbio (Rome, Italie). L'Anthropologie 93, 749-782.

Backwell, L.R., d'Errico, F., 2001. Evidence of termite foraging by Swartkrans early hominids. Proc. Natl. Acad. Sci. 98, 1358-1363.

Barandiarán, Veiga Ferreira, I., Da, O., 1971. Huesos labrados en el Paleolitico antíguo y médio de Portugal. Arqueologia e História 9 (3), 7-30.

Biberson, P., Aguirre, E., 1965. Expériences de taille d'outils préhistoriques dans des os d'éléphant. Quaternaria 7, 165-183.

Biddittu, I., Celletti, P., 2001. Plio-Pleistocene proboscidea and Lower Palaeolithic bone industry of southern Latium (Italy). In: Cavarretta, G., Gioia, P., Mussi, M., Palombo, M.R. (Eds.), The World of Elephants. Proceedings of the First International Congress. Consiglio Nazionale delle Ricerche, Roma, pp. 91-96.

Biddittu, I., Segre, A.G., 1982. Utilizzazione dell'osso nel Paleolitico inferiore italiano. In: Atti XXI Riunione Scientifica Ist. It. Preist. e Protost., pp. 90-105.

Blasco, R., Rosell, J., Fernández, P.J., Cáceres, I., María Vergès, J., 2008. A new element of trampling: an experimental application on the Level XII faunal record of Bolomor Cave (Valencia, Spain). J. Archaeol. Sci. 35, 1605-1618.
Blasco, R., Rosell, J., Cuartero, F., Fernández, P.J., Gopher, A., Barkai, R., 2013. Using Bones to Shape Stones: MIS 9 Bone Retouchers at Both Edges of the Mediterranean Sea. Plos One 8, 10.

Blumenshine, R.J., 1995. Percussion marks, tooth marks, and experimental determinations of the timing of hominid and carnivore ace to long bones at FLK Zinjanthropus, Olduvai Gorge, Tanzania. J. Human Evol. 27, 197-213.

Bordes, F., 1961. Typologie du Paléolithique ancien et moyen. Cahiers du Quaternaire 1, 112.

Brain, C.K., 1981. The Hunters or the Hunted? An Introduction to African Cave Taphonomy. University of Chicago Press, Chicago.

Broglio, A., Tagliacozzo, A., De Stefani, M., Gurioli, F., Facciolo, A., 2006. Aurignacian dwelling structures hunting strategies and seasonality in the Fumane Cave (Lessini Mountains). In: Vasil'ev, V.V., Popov, V.V., Anikovich, M.V., Praslov, N.D., Sinitsyn, A.A., Hoffecker, J.F. (Eds.), The early Upper Palaeolithic of Eurasia: general trends, local developments. State Archaeological Museum-reserve, Kostenki, pp. 263-268

Cabrera Valdes, V., 1984. El yacimiento de la Cueva de El Castillo. Bibliotheca Praehistorica Hispana, Madrid.

Carbonell, E., Cebrià, A., Allué, E., Cáceres, I., Castro, Z., Díaz, R., Esteban, M., Ollé; A., Pastó; I., Rodríguez, X.P., Rosell, J., Sala, R., Vallverdú, J., Vaquero, M., Vergés, J.M., 1996. Behavioural and organizational complexity in the Middle Palaeolithic from Abric Romaní. In: Carbonell, E., Vaquero, M. (Eds.), The last Neanderthals, the first Anatomically Modern Humans: a tale about the human diversity. Universitat Rovira i Virgili, Tarragona, pp. 385-434

Cassoli, P.F., De Giuli, C., Radmilli, A.M., Segre, A.G., 1982. Giacimento del paleolitico inferiore a Malagrotta (Roma). In: Atti XXIII Riunione Scientifica I.I.P.P, pp. 531-549.

Chase, P.G., Nowell, A., 1998. Taphonomy of a suggested Middle Palaeolithic bone flute from Slovenia. Curr. Anthropol. 39, 549-553.

Christidou, R., (Unpublished Ph.D. dissertation) 1999. Outils en os néolithiques du Nord de la Grèce: étude technologique. University of Paris X, France.

d'Errico, F., Henshilwood, C.S., 2007. Additional evidence for bone technology in the southern African Middle Stone Age. J. Human Evol. 52, $142-163$.

d'Errico, F., Villa, P., 1997. Holes and grooves: The contribution of microscopy and taphonomy to the problem of art origins. J. Human Evol. 33, 1-31.

d'Errico, E., Villa, P., Pinto Llona, A.C., Ruiz Idarraga, R., 1998. A Middle Palaeolithic origin of Music? Using cave-bear accumulations to assess the Divje babe I bone flute. Antiquity 72, 39-41.

Dobosi, V.T., 2001. Ex Proboscideis-Proboscidean remains as raw material at four Palaeolithic sites, Hungary. In: Cavarretta, G., Gioia, P., Mussi, M., Palombo, M.R. (Eds.), The World of Elephants. Proceedings of the First International Congress. Consiglio Nazionale delle Ricerche, Roma, pp. 429-431.

Domínguez-Rodrigo, M., Piqueras, A., 2003. The use of tooth pits to identify carnivore taxa in tooth-marked archeofaunas and their relevance to reconstruct hominid carcass processing behaviors. J. Archaeol. Sci. 30, 1385-1391.

Domínguez-Rodrigo, M., de Juana, S., Galán, A.B., Rodríguez, M., 2009. A new protocol to differentiate trampling marks from butchery cut marks. J. Archaeol. Sci. 36, 2643-2654.

Fischer, J.W., 1995. Bone surface modifications in zooarchaeology. J. Archaeol. Method Theory 2, 7-68.

Galán, A.B., Rodríguez, M., de Juana, S., Domínguez-Rodrigo, M., 2009. A new experimental study on percussion marks and notches and their bearing on the interpretation of hammerstone-broken faunal assemblages. J. Archaeol. Sci. 36, 776-784.

Gaudzinski, S., 1999. Middle Palaeolithic Bone Tools from the OpenAir Site Salzgitter-Lebenstedt (Germany). J. Archaeol. Sci. 26, 125-141.

Gaudzinski, S., Turner, E., Anzidei, A.P., Álvarez-Fernández, E., ArroyoCabrales, J., Cinq-Mars, J., Dobosi, V.T., Hannus, A., Johnson, E., Münzel, S.C., Scheer, A., Villa, P., 2005. The use of Proboscidean remains in every-day Palaeolithic life. Quatern. Internat. 126-128, 179-194.

Henshilwood, C.S., d'Errico, F., Marean, C.W., Milo, R.G., Yates, R., 2001. An early bone tool industry from the Middle Stone Age at Blombos Cave, South Africa: implications for the origins of modern human behaviour, symbolism and language. J. Human Evol. 41, 631-678.

Higham, T.F.G., Brock, F., Peresani, M., Broglio, A., Wood, R., Douka, K., 2009. Problems with radiocarbon dating the Middle and Upper Palaeolithic transition in Italy. Quaternary Sci. Rev. 28, 1257-1267.

Jéquier, C.A., Romandini, M., Peresani, M., 2012. Les retouchoirs en matières dures animales : une comparaison entre Moustérien final et Uluzzien. C. R. Palevol. 11 (4), 283-292. 
Koby, F.E., 1943. Les soi-disant instruments osseux du Paléolithique alpin et le charriage à sec des os d'ours des cavernes. Verhandlungen der Naturforschenden Gesellschaft in Basel 54, 59-95.

Legrand, A., 2007. Fabrication et utilisation de l'outillage en matières osseuses du Néolithique de Chypre: Khirokitia et Cap AndreasKastros, BAR International Series, Oxford, 1678 p.

Maigrot, Y., 1997. Tracéologie des outils tranchants en os des Ve et IVe millenaires av. J.-C. en Bassin parisien. Essai méthodologique et application. Bull. Soc. Prehist. Fr. 94 (2), 198-216.

Mania, D., Mania, U., 2005. The natural and sociocultural environment of Homo erectus at Bilsleben, Germany. In: Gamble, C., Porr, M. (Eds.), The Hominin Individual in Context: Archaeological investigations of Lower and Middle Palaeolithic Landscapes, locales and artifacts. Routledge, London, pp. 98-114.

McBrearty, S., Brooks, A.S., 2000. The revolution that wasn't: a new interpretation of the origin of modern human behavior. J. Human Evol. 39, 453-563.

Morin, E., 2010. Taphonomic implications of the use of bone as fuel. In: Théry-Parisot, I., Chabal, L., Costamagno, S. (Eds.), The taphonomy of burned organic residues and combustion features in archaeological contexts, 2. Palethnologie, pp. 215-223.

Mozota Holgueras, M., 2009. El utillaje óseo musteriense del nivel D de Axlor (Dima, Vizcaya): análisis de la cadena operativa. Trabajos de Prehistoria 66, 27-46.

Olsen, S.L., 1989. On distinguishing natural from cultural damage on archaeological antler. J. Archaeol. Sci. 16 (2), 125-135.

Peresani, M., 2012. Fifty thousand years of flint knapping and tool shaping across the Mousterian and Uluzzian sequence of Fumane cave. Quatern. Internat. 247, 125-150.

Peresani, M., Chravzez, J., Danti, A., De March, M., Duches, R., Gurioli, F., Muratori, S., Romandini, M., Tagliacozzo, A., Trombino, L. 2011a. Fire-places frequentations and the environmental setting of the final Mousterian at Grotta di Fumane: a report from the 2006-2008 research. Quartär 58, 131-151

Peresani, M., Fiore, I., Gala, M., Romandini, M., Tagliacozzo, A., 2011b. Late Neandertals and the intentional removal of feathers as evidenced from bird bone taphonomy at Fumane Cave 44 ky B.P. Italy. Proc. Natl. Acad. Sci. 108, 3888-3893.

Romandini, M., Nannini, N., Tagliacozzo, A., Peresani, M., 2014. The ungulate assemblage from layer A9 at Grotta di Fumane, Italy: a zooarchaeological contribution to the reconstruction of Neanderthal ecology. Quatern. Internat. 1.

Rosell, J., Blasco, R., Campeny, G., Carlos Díez, J., Alonso Alcalde, R., Menéndez, L., Arsuaga, J.L., Bermúdez de Castro, J.M., Carbonell, E., 2011. Bone as a technological raw material at the Gran Dolina site (Sierra de Atapuerca, Burgos, Spain). J. Human Evol. 61, 125-131.
Rosell, J., Blasco, R., Huguet, R., Cáceres, I., Saladié, P., Rivals, F., de Lluc Bennàsar, M., Bravo, P., Campeny, G., Esteban-Nadal, M., Cristina Fernández-Laso, C., Gabucio, J., Ibáñez, N., Martín, P., Muñoz, L., Antonio Rodríguez-Hidalgo, A., 2012. Occupational Patterns and Subsistence Strategies in Level J of Abric Romaní. In: Carbonell y Roura, E. (Ed.), High Resolution Archaeology and Neanderthal Behavior: Time and Space in Level J of Abric Romaní (Capellades, Spain). Vertebrate Paleobiology and Paleoanthropology, Springer Science, pp. 313- 372.

Saccà, D., 2012. Taphonomy of Palaeloxodon antiquus at Castel di Guido (Rome, Italy): Proboscidean carcass exploitation in the Lower Palaeolithic. Quatern. Internat. 276-277, 27-41.

Segre Naldini, E., Muttoni, M., Parenti, F., Scardia, G., Segre, A.G., 2009. Nouvelles recherches dans le bassin Plio-Pléistocène d'Anagni (Latium méridional, Italie). L'Anthropologie 113, 66-77.

Shipman, P., Rose, J., 1988. Bone tools: an experimental approach. In: Olsen, S.L. (Ed.), Scanning Electron Microscopy in Archaeology. BAR International Series 452, Oxford, pp. 303-335.

Soressi, M., McPherron, S.P., Lenoir, M., Dogandžić, T., Goldberg, P., Jacobs, Z., Maigrot, Y., Martisius, N.L., Miller, C.E., Rendu, W., Richards, M., Skinner, M.M., Steele, T.E., Talamo, S., Texier, J.P., 2013. Neandertals made the first specialized bone tools in Europe. PNAS 110 (35), 14186-14190.

Stephanchuk, V.N., 1993. Prolom II, a Middle Palaeolithic cave site in the eastern Crimea with non-utilitarian bone artefacts. Proc. Prehist. Soc. 59, 17-37.

Valensi, P., 1996. Taphonomie des grands mammifères et palethnologie à la Grotte du Lazaret (Nice, France). Anthropozoologica 23, 13-28.

Villa, P., 1991. Middle Pleistocene prehistory in southwestern Europe: the state of our knowledge and ignorance. J. Anthropol. Res. 47, 193- 217.

Villa, P., Bartram, L., 1996. Flaked bone from a Hyena den. Paleontology 8, 143-159.

Villa, P., d'Errico, F., 2001. Bone and ivory points in the Lower and Middle Paleolithic of Europe. J. Human Evol. 41, 69-112.

Villa, P., Anzidei, A.P., Cerilli, E., 1999. Bones and bone modifications at La Polledrara, a Middle Pleistocene site in Italy. The role of early humans in the accumulation of European Lower and Middle Palaeolithic bone assemblages, 42. Römisch-Germanisches Zentralmuseum, Monograph, pp. 197-206.

Vincent, A., 1988. L'os comme artefact au Paléolithique moyen : principes d'étude et premiers résultats. In: Binford, L., Rigaud, J.P. (Eds.), L'Homme de Neandertal. La Technique. ERAUL 31, pp. 185-196.

Vincent, A., (PhD Dissertation) 1993. L'outillage osseux au Paléolithique moyen : une nouvelle approche. University Paris X, 2 p.

Zilhão, J., Cardoso, J.L., Pike, A.W.G., Weninger, B., 2011. Gruta Nova da Columbeira (Bombarral, Portugal): site stratigraphy, age of the Mousterian sequence, and implications for the timing of Neanderthal extinction in Iberia. Quartär 58, 93-112. 